\title{
Factors Affecting Employees' Organizational Commitment in Foreign Direct Investment Enterprises
}

\author{
Thi Viet Nga NGUYEN ${ }^{1}$, Thanh Quang DO², Cong Hoang DINH ${ }^{3}$
}

Received: July 18, 2020 Revised: August 23, 2020 Accepted: August 28, 2020

\begin{abstract}
This study aims to develop a research framework to investigate the factors affecting organizational commitment among employees who are working in Foreign Direct Investment (FDI) enterprises in Vietnam. The authors designed an online survey distributed to employees in FDI enterprises, collecting the data from 312 employees. All scales in this study are adopted from previous studies; tools employed include Cronbach's Alpha, Exploratory Factor Analysis, and Confirmatory Factor Analysis (CFA) to examine the internal consistency, reliability, dimensionality, and validity of each variable. Then, the structural equation modelling (SEM) was utilized in order to estimate path correlations between variables. Results indicate that the leadership style has the strongest effect on organizational commitment, followed by job satisfaction and working performance. Moreover, working performance and job satisfaction are also influenced by leadership style. However, there is no statistical evidence to show that job satisfaction has an impact on working performance. In addition, bootstrapping method is used to show the indirect effect of variables; results reveal that leadership style, though, does not have indirect effect on working performance via job satisfaction, but it indirectly affects organizational commitment throughout working performance. In other words, the study finds that working performance mediates the link between leadership style and organizational commitment.
\end{abstract}

Keywords: Job Satisfaction, Organizational Commitment, Leadership Style, Working Performance, FDI Enterprises

JEL Classification Code: M10, M52, M54

\section{Introduction}

Organizational commitment is considered to be one of the most important work attitudes that gives direction to behavior and binds a person to a course of action. When employees are committed, they do not tempt to look for other opportunities (Lok \& Crawford, 2001). Mowday et al. (1979) states that organizational commitment is obtained when employees strongly believe in and accept the goals and values of an organization, when they are willing to do their utmost on behalf of the organization and to stay with

${ }^{1}$ First Author and Corresponding Author. Department of Economics, Academy of Finance, Hanoi, Vietnam [Postal Address: 58 Le Van Hien, Bac Tu Liem District, Hanoi, 100000, Vietnam]

Email: ngahvtc1605@gmail.com

${ }^{2}$ Department of Ho Chi Minh City Customs, Ho Chi Minh City, Vietnam. Email: stevedo456789@gmail.com

${ }^{3}$ Insitude for Africa and Middle East, Vietnam Academy of Social Sciences (VASS), Vietnam. Email: hoang0108@gmail.com.

(c) Copyright: The Author(s)

This is an Open Access article distributed under the terms of the Creative Commons Attribution Non-Commercial License (https://creativecommons.org/licenses/by-nc/4.0/) which permits unrestricted non-commercial use, distribution, and reproduction in any medium, provided the original work is properly cited. the organization. Organizational commitment serves as an important factor impacting several outcome variables including job satisfaction, work performance, turnover rate, leading to the higher level of achievement in many organizations. Organizations try to encourage commitment in their employees in order to achieve stability and improve the efficiency of its human capital. With the increasing speed and scale of changes in organizations, managers are constantly seeking ways to generate greater employees' commitment and competitive advantage (Lok \& Crawford, 2001). Furthermore, Schuster (1998, p. 51) contends "in an era in which organizations frequently confront the necessity of massive change, committed employees can be extremely valuable organizational resource in facilitating rapid adaptation to changing conditions". Thus, for organizations that want to retain their employees, it is important to recognize factors leading to higher organizational commitment.

Moreover, most of the research on organizational commitment (OC) has been conducted in Western countries and the models on this subject have often been developed and investigated in Western countries too (Meyer \& Allen, 1991). In Vietnam, organizational commitment is a topic that has not been studied much and there is a lack of academic 
research on this issue (Thang, 2003). In reality, not only in the developed economies, but also in developing economies such as Vietnam, managers in organizations face many difficulties in how to retain talents and motivate them to stay with and grow with their organization as well. Because organizational commitment is considered as an important factor in keeping talented employees, employees must be encouraged to participate in corporate activities and thereby strengthening the employees' commitment over the longterm and the stable development of the organization. This issue becomes even more important in the current context of Vietnam's economy in line with the globalization trend in trade activities and ever-changing business environment to obtain sustainable development. Thus, it is also important to develop research on organizational commitment to support managers to make effective and efficient managing decision especially in human resource management by identify comprehensive perspectives on the topic.

This study aims to explore the effects of factors, including leadership style, job satisfaction, and work performance, on the organizational commitment in Foreign Direct Investment (FDI) enterprises in Vietnam. Moreover, the mediating roles of job satisfaction in the linkage between leadership lifestyle, work performance and organizational commitment are also discovered in this research.

\section{Literature Review}

\subsection{Organizational Commitment}

Since the 1970s, organizational commitment is one of the interesting topics that have caught significant attention from many researchers in different workplaces; studies on this topic have developed continuously with a valuable contribution not only to scholarship, but also to practical applications, which are useful for managers in organizations. The results of this research show that organizational commitment is a topic, which can be defined in different ways or seen in terms of diversity. In addition, the definition of this topic is inconsistency (Zin, 1998), which leads to difficulties in accessing and understanding the implications of the research (Darolia et al., 2010). The different perspectives on this topic, which are summarized, show that the nature of organizational commitment is examined in terms of attitudes and behaviors. It is not important whether the commitment process begins with attitudes or behaviors, but more importantly in how relevant their interactions are with behaviors (Mowday et al., 1982).

Although there are several conceptualization of commitment, they seem to reflect one of three general themes: affective attachment, perceived costs, and obligation (Meyer $\&$ Allen, 1991). For several authors, the term commitment is used to describe an effective orientation toward the organization. In the affective attachment approach, the most frequently mentioned definition of organizational commitment was evolved by Mowday et al. (1979). They conceptualized organizational commitment as the relative strength of an individual's identification with involvement in a particular organization (Mowday et al. 1979). According to Allen and Meyer (1990), ensuring continuous and desirable work outcomes of employees lead to positive impact on organizational commitment of employees. In such circumstances, employees easily accept the organizational culture of the company. Vuong et al. (2020) showed that dimensions of transformational leadership and employees' trust in managers have a significantly positive influence on organizational commitment. In addition, Jatmiko et al., (2020) also reveals that contingent reward has a significant correlation with affective and normative commitment. Meanwhile, transformational leadership style was not found to have an effect on organizational commitment.

In addition, organizational commitment also reflects efforts to complete the task, being proud to be a member of the organization, and loyalty to the organization. When the persons' extraneous interest exists consistently, it becomes a commitment (Becker, 1960). Organizational commitment is a degree of attachment to the organization seen as commitment (O'Reilly \& Chatman, 1986). It has three major components, including a strong belief in the organization and acceptance of the organizations' goals, a willingness to exert considerable effort on behalf of the organization, and a definite desire to maintain organizational membership (Mowday et al., 1979). Major three dimensions of commitments are complaining, identification, and moral (O’Reilly \& Chatman, 1986). Organizational commitment is a psychological contract that describes the employees' relationship to the organization and is meaningful for decisions to continue or stop being a membership of the organization, which focused on the three psychological states of commitment - effective commitment means that the employee wants to stay in the organization from their sincere feelings, continuance commitment refers to the perception of the involved costs when leaving the organization, they realize that it has no chance of finding a better job, and normative commitment of personal responsibility or the ethical standards they pursue to work in the organization (Meyer \& Allen, 1991). It is defined as a positive evaluation of organization and purpose of work toward the goal of the organization (Sheldon, 1971). It is described it as support, giving affection for the organizational goals and values, where the role of the employee is to work for the pure goals and values related to the organization (Buchanan, 1974). There have been many research efforts to identify factors that explain the organizational commitment behavior among 
employees in the FDI enterprises. Research has been done to obtain knowledge related to factors that foster employees' organizational commitment (Becker, 1960; Mowday et al., 1979; O’Reilly \& Chatman, 1986; Meyer \& Allen, 1991).

\subsection{The Effect of Work Performance}

Performance is determined as the period of accumulation to achieve certain work (Simanjuntak, 2011). It reflects that work performance is a period of achievement accumulated by the individual via their work. Eliyana and Muzakki (2018) emphasized that work performance in organization is definitely influenced by three major antecedents: organizational support, management effectiveness or capacities, and work performance of each individual who work at that organization. Rivai et al. (2008) state that work performance is related to working and achievement that derived from work while Eliyana and Muzakki (2018) argue that working performance is examined as an individual' capacities to perform activities that contribute to the organizational development. Nimalathasan (2010) examined the relationship between employees' level job satisfaction and performance among employees of People's Bank in Jaffna Peninsula, Sri Lanka. The results of the study revealed that there is a positive relationship between job satisfaction and employees' work performance. There is a high level of fair promotion, reasonable pay system, appropriate work itself and good working condition that leads to high level of employees' performance.

It is noteworthy that previous studies reported positive correlations between commitment and work performance. Meyer and Allen (1991), however, argued that since affective, calculative, and normative commitment reflected three different mindsets, they would have distinguishable implications on the outcome behaviors. The desire to belong to the organization (affective commitment) might be the most likely to have a positive correlation with job performance (Ahmad et al., 2010; Hettiarachchi \& Jayaeathua, 2014).

H1: Working performance is positively related to organizational commitment.

\subsection{The Effect of Job Satisfaction}

Job satisfaction is an interesting or a positive feeling from the evaluation of one's job or work experience. In the organization, job satisfaction will create positive relationships with employees and retain more engaged employees in the workplace (Tett \& Meyer, 1993). Employees, who are satisfied with their work, tend to stay, in contrast to others who are less satisfied, less likely to stay over in their organization (Dong \& Phuong, 2018). Employees who experience positive situations at workplace will be more satisfied at work, and ultimately their job satisfaction will enhance organizational commitment (Martono et al., 2020). Thus, job satisfaction is seen as one of the important factors that can shape organizational commitment among employees (Nguyen \& Tu, 2020). Job satisfaction is also defined as the level of "favorableness or un favorableness with which workers view their job" (Werther \& Davis, 1999, 501). It reflects employees' general opinion regarding their career. So, a person with high level of job satisfaction lead to positive feelings and emotion related to his/her job. In other words, an individual who are unsatisfactory with his job can have negative attitude towards his duties, then results in lower work performance and organizational commitment (Robbins \& Coulter, 2005).

Job satisfaction is also defined by how far employees/ worker are satisfied with their working (Furnham et al., 2009). These two constructs are mutually discussed, the reason is that a person who is satisfied in workplace can have higher motivation to improve his/her productivity as well as have a strong attachment to his/her company. Also, job satisfaction has a linkage with work performance. A company with more satisfied employees seems to be more effective and productive (Chen, 2006; Kertabudi \& Aripin, 2015).

H2: Job satisfaction is positively related to work performance

H3: Job satisfaction is positively related to organization commitment.

\subsection{The Effect of Leadership Style}

Bethel (1995) argues that leadership has a strong ability to affect employee. Leadership is divided into two types: transactional and transformational leadership (Bass, 1997). Hellriegel and Slocum (2006) state that transactional leadership is based on three primary components: contingent reward, active management by exception, and passive management by exception. Tichy and Devanna (1986) presented characteristics regarding the estimation of transformational leadership, including qualities, courage, openness, values, learning and ability of visionary. Leadership style is also reflected in the level of interest of an employee in a higher position for an employee in a lower position in an organization (Currivan, 1999). Leadership styles include the attitude, interest, words, gestures, and actions that superiors or administrators have toward their employees. When employees feel well treated, they receive the attention, support, sympathy and appreciation from their superiors, they will strive to work and desire to contribute more to the organization (Currivan, 1999; Scheweizer \& Petzelt, 2012). Purvanova et al., 2006) explained that 
transformational leadership played a very important role in creating job commitment). Positive behavior of leaders can foster motivation and employee commitment (Akinboye, 2005; Lo et al., 2009). Swanepoel et al. (2000) describe the organizational commitment is encouraged with the leadership style for the successful implementation of business strategies to achieve the organizational goal.

In addition, leadership style and employee job satisfaction are the cornerstones of organizational effectiveness. Leadership style determines job satisfaction (Lo et al., 2009; Long et al., 2014). It affects employees' motivation and commitment both of which affect the performance of an organization, both in the immediate and longer terms. Therefore, improving leadership style and management capability is an issue that no organization wishing to achieve long-term success can ignore.

H4: Leadership style is positively related to job satisfaction

H5: Leadership style is positively related to work performance

H6: Leadership style is positively related to organizational commitment.

Figure 1 describes the conceptual framework.

\section{Methodology}

\subsection{Sampling}

The questionnaire is distributed via email to 1,500 employees who are working in Foreign Direct Investment (FDI) enterprises in Vietnam. However, only 338 employees fulfilled the survey's requirements, reaching $22.53 \%$. After removing 26 questionnaires because of blank forms or insufficient responses, the study includes 312 respondents.

The demographic information is represented in Table 1. Results reveal that $53.2 \%$ of employees are male, with $46.8 \%$ female. $33.7 \%$ employees are aged from 25 to 34, followed by $28.5 \%$ aged from 34 to $44,26.9 \%$ who are over 44 and $10.9 \%$ who are less than 25 . More than a half of employees are single, accounts for $56.4 \%$, while $63.8 \%$ hold a bachelor degree. In terms of working experience, $36.9 \%$ of employees have been working from 4 to 6 years, $22.8 \%$ and $22.4 \%$ of them have been working for companies more than 6 years and from 1 to 3 years, respectively. Moreover, $36.5 \%$ of employees are paid between USD500 and USD1000 each month, $36.5 \%$ have a salary from USD1000 to USD2000, and only $14.7 \%$ have a salary higher than USD2000.

\subsection{Measures}

All scales were adopted from prior studies, "leadership style" adapted from Bass and Avoho (2004) (1 = strongly disagree; 5 = strongly agree); "work performance" adopted from Dinc (2017) ranged from $1=$ very poor to $5=$ very good; "Job satisfaction" taken from Liu and Bellibas (2018) and organization commitment adapted from Rajabi et al. (2019) with $1=$ strongly disagree; $5=$ strongly agree.

\subsection{Analysis}

This study uses a quantitative research method through four major stages. Firstly, Cronbach's Alpha and exploratory factor analysis (EFA) were employed to test internal consistency reliability of each variable in the research model. Secondly, confirmatory factor analysis (CFA) was utilized to show the model fit, dimensionality, validity, and reliability of variables. Thirdly, structural equation modelling (SEM) was used to test hypotheses (path coefficients) and the effect of factors on organizational commitment in the research model. Finally, the bootstrapping method was applied to estimate the mediating roles of job satisfaction, work performance in the linkage between leadership style and organizational commitment as well as the 'work performance' mediator in the relationship between job satisfaction and organizational commitment.

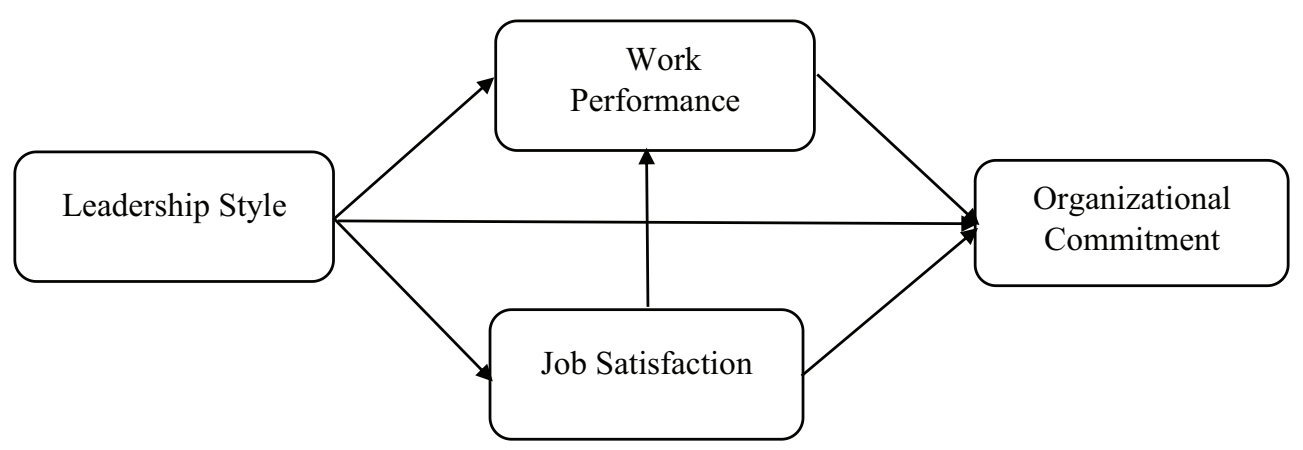

Figure 1: Conceptual Framework 
Table 1: Demographic information of respondents

\begin{tabular}{|l|l|c|c|}
\hline Demographic information & Frequency & Percent \\
\hline \multirow{4}{*}{ 1. Gender } & Male & 166 & 53.2 \\
\cline { 2 - 4 } & Female & 146 & 46.8 \\
\hline \multirow{5}{*}{ 2. Age (years old) } & $<25$ & 34 & 10.9 \\
\cline { 2 - 4 } & $25-34$ & 105 & 33.7 \\
\cline { 2 - 4 } & $34-44$ & 89 & 28.5 \\
\cline { 2 - 4 } & $>44$ & 84 & 26.9 \\
\hline \multirow{3}{*}{ 3. Marital status } & Single & 176 & 56.4 \\
\hline \multirow{4}{*}{4. Educational level } & Married & 136 & 43.6 \\
\hline \multirow{5}{*}{5. Working experience (years) } & High School & 33 & 10.6 \\
\cline { 2 - 4 } & Bachelor & 199 & 63.8 \\
\cline { 2 - 4 } & Master & 80 & 25.6 \\
\hline \multirow{5}{*}{6. Income (per month) } & $<1$ & 56 & 22.4 \\
\cline { 2 - 4 } & $1-3$ & 70 & 36.9 \\
\cline { 2 - 4 } & $4-6$ & 715 & 22.8 \\
\cline { 2 - 4 } & $>6$ & 17 & 5.4 \\
\hline & $<250$ USD & 135 & 33.3 \\
\cline { 2 - 4 } & $250-400$ USD & 114 & 36.5 \\
\cline { 2 - 4 } & $400-600$ USD & 46 & 14.7 \\
\cline { 2 - 4 } & $>600$ USD & & \\
\hline
\end{tabular}

Note: $\mathrm{N}=312$

\section{Results}

\subsection{Cronbach's Alpha and Exploratory Factor Analysis}

Table 2 reveals that Cronbach' Alpha of "Leadership Style-LS", "Working Performance-WP", "Job SatisfactionJS" and "Organizational Commitment-OC" reached 0.903, $0.822,0.794$ and 0.836 , respectively. Thus, all scales are satisfactory for further analysis. Moreover, exploratory factor analysis is employed. Results showed that KaiserMeyer-Olkin measure of sampling adequacy $(\mathrm{KMO})=0.858$, Sig. Of Bartlett's test of sphericity $<0.001$; Cumulative (\%) $=71.239$; Eigenvalues =1.178; and all items had loaded on four factors. All scales, therefore, are appropriate for confirmatory factor analysis (CFA).

\subsection{Confirmatory Factor Analysis}

The results of confirmatory factor analysis (CFA) revealed that the measurement model has good fit level: Chi-square $=105.644$, Chi-square $/ \mathrm{df}=1.488<5$;
$\mathrm{GFI}=0.952 ; \mathrm{AGFI}=0.929 ; \mathrm{CFI}=0.983 ; \mathrm{TLI}=0.979 ; \mathrm{NFI}$ $=0.951>0.9$; RMSEA $=0.040<0.05$ (Bentler $\&$ Bonnett, 1980; Kettinger \& Lee, 1995). Also, the CFA results showed that all standardized regression weights are higher than 0.6, the lowest value of standardized regression weights is 0.679 (JS1). All scales have average variance extracted (AVE) and composite reliability (CR) are higher than 0.5 . Thus, all variables in the research model reach the validity and discriminant values (see Table 3).

\subsection{Structural Equation Modelling}

The results of structural equation modelling revealed that structural model also have good fit level: Chi-square $=105.644$, Chi-square $/ \mathrm{df}=1.488<5$; GFI $=0.952 ;$ AGFI $=0.929 ; \mathrm{CFI}=0.983 ; \mathrm{TLI}=0.979 ; \mathrm{NFI}=0.951>0.9 ; \mathrm{RMSEA}$ $=0.040<0.05$ (see Figure 2).

A total of six hypotheses were tested in the study (see Table 4). Five of them are statistically supported, while only one was rejected. In particular, working performance was positively related to organization $(\beta=0.127 ; p$-value $=0.030$ $<0.05$ ) (H1 was supported). However, job satisfaction did not 
Table 2: The results of testing internal consistency reliability of each scales

\begin{tabular}{|c|c|c|c|c|c|}
\hline \multirow{2}{*}{ Constructs } & \multirow{2}{*}{ Items } & \multicolumn{4}{|c|}{ Component } \\
\hline & & LS & WP & JS & OC \\
\hline \multirow{5}{*}{$\begin{array}{l}\text { Leadership style (LS) } \\
\text { (Bass \& Avoho, 2004) }\end{array}$} & LS1. Superiors are very close, friendly to me & 0.443 & & & \\
\hline & $\begin{array}{l}\text { LS2. I am completely satisfied with the leadership style at the } \\
\text { organization }\end{array}$ & 0.570 & & & \\
\hline & LS3. My superiors often encourage me in the workplace. & 0.827 & & & \\
\hline & LS4. I have always respected by superiors & 0.816 & & & \\
\hline & LS5. I have always been treated fairly & 0.761 & & & \\
\hline \multirow{3}{*}{$\begin{array}{l}\text { Work Performance } \\
\text { (WP) } \\
\text { (Dinc, 2017) }\end{array}$} & WP1. How your boss would rate your overall at work & & 0.666 & & \\
\hline & WP2. How you rate your own overall performance & & 0.838 & & \\
\hline & WP3. How your colleagues would rate your overall performance & & 0.860 & & \\
\hline \multirow[t]{3}{*}{$\begin{array}{l}\text { Job satisfaction (JS) } \\
\text { (Liu \& Bellibas, 2018) }\end{array}$} & $\begin{array}{l}\text { JS1. The advantages of this profession clearly outweigh } \\
\text { disadvantage }\end{array}$ & & & 0.672 & \\
\hline & JS2. I am satisfied with my performance in this company & & & 0.758 & \\
\hline & JS3. All in all, I am satisfied with my job & & & 0.817 & \\
\hline \multirow{3}{*}{$\begin{array}{l}\text { Organizational } \\
\text { Commitment (OC) } \\
\text { (Rajabi et al., 2019) }\end{array}$} & OC1. I feel like "part of family" at this agency & & & & 0.779 \\
\hline & OC2. enjoy discussing my agency with people outside it & & & & 0.921 \\
\hline & $\begin{array}{l}\text { OC3. It would be very happy to spend the rest of my career with } \\
\text { this agency }\end{array}$ & & & & 0.906 \\
\hline \multicolumn{2}{|l|}{ Cronbach' Alpha } & 0.903 & 0.822 & 0.794 & 0.836 \\
\hline \multicolumn{2}{|c|}{ Kaiser-Meyer-Olkin Measure of Sampling Adequacy (KMO) } & \multicolumn{4}{|c|}{0.858} \\
\hline \multicolumn{2}{|c|}{ Sig. Of Bartlett's Test of Sphericity } & \multicolumn{4}{|c|}{0.000} \\
\hline \multicolumn{2}{|c|}{ Cumulative (\%) } & \multicolumn{4}{|c|}{71.239} \\
\hline \multicolumn{2}{|l|}{ Eigenvalues } & \multicolumn{4}{|c|}{1.178} \\
\hline
\end{tabular}

Table 3: The convergent and discriminant validity of scales

\begin{tabular}{|l|c|c|c|c|c|c|c|c|}
\hline & CR & AVE & MSV & MaxR(H) & WP & LS & OC & JS \\
\hline Work Performance (WP) & 0.832 & 0.625 & 0.088 & 0.851 & 0.791 & & & \\
\hline Leadership Style (LS) & 0.839 & 0.513 & 0.399 & 0.849 & 0.297 & 0.716 & & \\
\hline Organizational Commitment (OC) & 0.904 & 0.759 & 0.288 & 0.920 & 0.295 & 0.537 & 0.871 & \\
\hline Job Satisfaction (SJ) & 0.797 & 0.568 & 0.399 & 0.806 & 0.276 & 0.632 & 0.486 & 0.754 \\
\hline
\end{tabular}

affect directly on working performance $(\beta=0.147$; $p$-value $=0.120>0.05)(\mathrm{H} 2$ was rejected $)$ while organizational commitment was strongly influenced by job satisfaction $(\beta=0.224 ;$ p-value $=0.006<0.01)(\mathrm{H} 3$ was supported $)$. Leadership play important role in predicting job satisfaction ( $\beta=0.632$; $p$-value $<0.001)$ (H4 was supported), working performance $(\beta=0.240$; $p$-value $=0.029<0.05)$ (H5 was supported), organizational commitment $(\beta=0.358$; $p$-value $<0.001$ ) (H6 was supported).
As mentioned, the bootstrapping method was employed to estimate indirect effects (1000 replications). Results showed that leadership style did not have indirect impact on working performance $(\beta=0.093$; $p$-value $=0.144>0.05)$ through job satisfaction, which also did not indirectly affect organizational commitment $(\beta=0.019$; $p$-value $=0.178>0.05)$. However, this study investigated that working performance mediated the relationship between leadership style and organizational commitment $(\beta=0.179$; $p$-value $=0.004<0.01)$. 


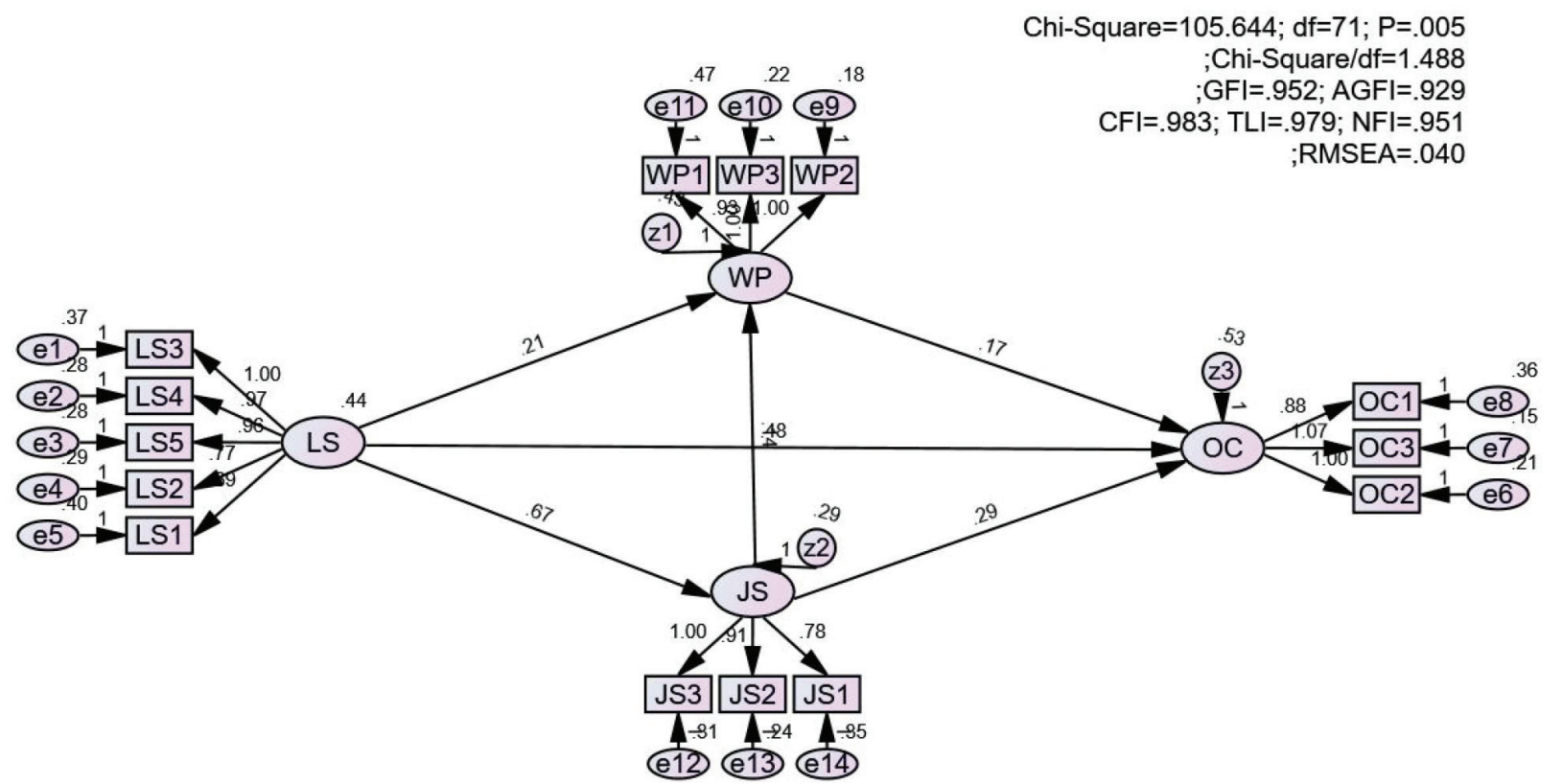

Figure 2: Structural equation modelling

Table 4: Direct and indirect effects (standardized estimates)

\begin{tabular}{|l|l|c|l|c|c|c|}
\hline Direct effects/Hypotheses & Estimate & P-value & Conclusion \\
\hline H1 & Working Performance & $\rightarrow$ & Organizational Commitment & 0.127 & 0.030 & Supported \\
\hline H2 & Job Satisfaction & $\rightarrow$ & Working Performance & 0.147 & 0.120 & Not Supported \\
\hline H3 & Job Satisfaction & $\rightarrow$ & Organizational Commitment & 0.224 & 0.006 & Supported \\
\hline H4 & Leadership Style & $\rightarrow$ & Job Satisfaction & 0.632 & $* * *$ & Supported \\
\hline H5 & Leadership Style & $\rightarrow$ & Working Performance & 0.240 & 0.029 & Supported \\
\hline H6 & Leadership Style & $\rightarrow$ & Organizational Commitment & 0.358 & $* * *$ & Supported \\
\hline Indirect effects & \multicolumn{2}{|c|}{ Leadership Style } & \multicolumn{2}{|c|}{ Job Satisfaction } \\
\hline \multicolumn{2}{|r|}{$0.093(0.144)$} \\
\hline Working Performance & $0.179(0.004)$ & \multicolumn{2}{c|}{0.000} \\
\hline Organizational Commitment & $0.178)$ \\
\hline
\end{tabular}

Note: ${ }^{* *}<0.001$

\section{Conclusion}

The research was conducted in the context of FDI enterprises in order to explore the factors that predict organizational commitment. The study mainly focused on how working performance, job satisfaction, and leadership style shape organizational commitment. Also, the study investigated the effect of leadership style on job satisfaction and working performance as well as discovering the mediating roles of job satisfaction and working performance in the link between leadership style and organizational commitment. Results showed that leadership style was positively related to job satisfaction, working performance and organizational commitment. Job satisfaction shows the important role in the increase of organization commitment, but not indicate the effect on working performance. In 
addition, the relationship between working performance and organizational commitment is significant. Moreover, the study confirmed that working performance plays the mediating role in the relationship between leadership style and organizational commitment.

\section{References}

Ahmad, H., Ahmad, K., \& Shah, L. A. (2010). Relationship between job satisfaction, job performance, attitude towards works and organizational commitment. European Journal of Social Science, 8(2), 257-267.

Akinboye, J. (2001). Executive behavior battery. Ibadan, Nigeria: Stirling-Horden Publishers.

Allen, N. J., \& Meyer, J. P. (1990). The measurement and antecedents of affective, continuance and normative commitment to the organization. Journal of Occupational and Organizational Psychology, 63, 1-18.

Bass, B. M., \& Avoho, B. J. (2004). Multifactor leadership questionnaire: manual and sampler set. Menlo Park, CA: Mind Garden, Inc.

Bass, B. M. (1997). Does the transactional-transformational leadership paradigm transcend organizational and national boundaries? American Psychologist, 52(2), 130-139.

Becker, H. S. (1960). Notes on the concept of commitment. American Journal of Sociology, 66(1), 32-40.

Bentler, P. M., \& Bonett, D. G. (1980). Significance tests and goodness of fit in the analysis of covariance structures. Psychological Bulletin, 88(3), 588-606.

Bethel, S. M. (1995). Servant-leadership and Corporate Risk Taking: When Risk Taking Makes a Difference. In: $L$. C. Spears (Ed.), Reflections on Leadership (pp. 135-148). New York, NY: John Wiley and Sons, Inc.

Buchanan, B. (1974). Building Organizational Commitment: The Socialization of Managers in Work Organizations. Administrative Science Quarterly, 19(4), 533-546.

Chen, C.-F. (2006). Job satisfaction, organizational commitment, and flight attendants' turnover intentions: A note. Journal of Air Transport Management, 12, 274-276.

Darolia, C, Kumaru, P., \& Farola, P. (2010). Perceived organizational support, work motivation, and organizational commitment as determinants of job performance. Journal of the Indian Academy of Applied Psychology, 36, 69-78.

Dinc, M. S. (2017). Organizational Commitment Components and Job Performance: Mediating Role of Job Satisfaction. Pakistan Journal of Commerce and Social Sciences, 11(3), 773-789.

Dong, L. N. T., \& Phuong, N. N. D. (2018). Organizational Justice, Job Satisfaction and Organizational Citizenship Behavior in Higher Education Institutions: A Research Proposition in Vietnam. The Journal of Asian Finance, Economics and Business, 5(3), 113-119. http://doi.org/10.13106/jafeb.2018. vol5.no3.113
Currivan, D. B. (1999). The causal order of job satisfaction and organizational commitment in models of employee turnover. Human Resource Management Review, 9(4), 495-524.

Furnham, A., Eracleous, A., \& Chamorro-Premuzic, T. (2009). Personality, motivation and job satisfaction: Hertzberg meets the Big Five. Journal of Managerial Psychology, 24(8), 765-779. http://dx.doi.org/10.1108/02683940910996789

Hellriegel, D., \& Slocum, J. W. (2006). Management of organizations. Paris, France: De Boeck Supérieur.

Hettiarachchi, H. A. H., \& Jayaeathua, S. M. D. Y. (2014). The effect of employer work related attitudes on employee job performance: A study of tertiary and vocational education sector in Sri Lanka. Journal of Business and Management, 16(4), 74-83.

Jatmiko, B., Laras, T., \& Rohmawati, A. (2020). Budgetary Participation, Organizational Commitment, and Performance of Local Government Apparatuses. Journal of Asian Finance, Economics and Business, 7(7), 379-390. https://doi. org/10.13106/jafeb.2020.vol7.no7.379

Kertabudi, I. S., \& Aripin. (2015). Effect organizational commitment and job satisfaction on employees performance at Cibabat Hospital, Cimahi City West Java. Australian Journal of Basic and Applied Science, 9(33), 346-351

Keltinger, W. J., \& Lee, C. C. (1999). Replication of Measures of Information Systems Research: The Case of IS SERVQUAL. Decision Sciences, 30(3), 893-899.

Furnham, A., Eracleou, A., \& Chamorro-Premuzic, T. (2009). Personality, motivation and job satisfaction: Hertzberg meets the Big Five. Journal of Managerial Psychology, 24(8), 765779.

Lok, P., \& Crawford, J. (2001). Antecedents of organizational commitment and the mediating role of job satisfaction. Journal of Managerial Psychology, 16(8), 594-613.

Long, C. S., Yusoof, W. M. M., Kowang, T. O., \& Heng, L. H. (2014). The impact of transformational leadership style on job satisfaction. World Applied Sciences Journal, 29(1), 117-124.

Lo, M.-C., Ramayah, T., \& Min, H. W. (2009). Leadership styles and organizational commitment: a test in Malaysia manufacturing industry. African Journal of Marketing Management, 1(6), 133139

Liu, Y., \& Bellibas, M. S. (2018). School factors that are related to school principals' job satisfaction and organizational commitment, International Journal of Educational Research, 90, 1-19

Martono, S., Khoiruddin, M., Wijayanto, A., Ridloah, S., Wulansari, N. A., \& Udin, U. (2020). ncreasing Teamwork, Organizational Commitment and Effectiveness through the Implementation of Collaborative Resolution. Journal of Asian Finance, Economics and Business, 7(6), 427-437. https://doi. org/10.13106/jafeb.2020.vol7.no6.427

Mowday, R., Steers, R., \& Porter, L. (1979). The measurement of Organizational Commitment. Journal of Vocational Behavior, 14, 224-247. 
Monday, R. T., Porter, I. W., \& Steers, R. M. (1982). Employeeorganization linkage. The psychology of commitment absenteism, and turn over. London, UK: Academic Press Inc.

Meyer, J. P., \& Allen, N. J. (1991). A three-component concept of organizational commitment. Human Resource Management Review, 1(1), 61-89.

Nguyen, T. H., \& Tu, V. B. (2020). Social Responsibility, Organizational Commitment, and Organizational Performance: Food Processing Enterprises in the Mekong River Delta. Journal of Asian Finance, Economics and Business, 7(2), 309-316. https://doi.org/10.13106/jafeb.2020.vol7.no2.309

Nimalathasan, B. (2010). Job Satisfaction and Employees' Work Performance: A Case Study of People's Bank in Jaffna Peninsula, Sri Lanka. Journal of Management and Marketing, 8(1), 43-47.

O'Reilly III, C., \& Chatman, J. (1986). Organizational Commitment and Psychological Attachment: The Effects of Compliance, Identification, and Internalization on Prosocial Behavior. Journal of Applied Psychology, 71(3), 492-499.

Purvanova, R. K., Bono, J. E., \& Dzieweczynski, J. (2006). Transformational leadership, job characteristics, and organizational citizenship performance. Human Performance, 19(1), 1-22.

Robbins, S. P., \& Coulter, M. (2005). Management. India: Pearson Education Inc. and Dorling Kindersley Publishing Inc.

Rivai, V., Sagala, E. J., Murni, S., \& Abdullah, B. (2008). Performance Appraisal. Jakarta, Indonesia: PT Raja Grafindo Persada.

Schuster, F. (1998). A strategy for high commitment and involvement: Employee centred management. London, UK: Quorum.

Schweizer, L., \& Patzelt, H. (2012). Employee commitment in the post-acquisition integration process: The effect of integration speed and leadership. Scandinavian Journal of Management, 28(4), 298-310.

Swanepoel, B., Erasmus, B., Van Wyk, M., \& Schenk, H. (2000). South African human resource management: Theory and practice. Cape Town, South Africa: Juta \& Co Ltd.

Simanjuntak, P. J. (2011). Management \& Job Evaluation (3rd ed.). Jakarta, Indonesia: Lembaga Penerbit Fakultas Ekonomi Universitas Indonesia.

Thang, N. V. (2003). Managing change in Vietnamese stateowned enterprises: What is the best strategy? Human Resource Management Review, 13, 423-438.

Tichy, N. M., \& Devanna, M. A. (1986). The transformational leader, Training \& Development Journal, 40(7), 27-32.

Rivai, V., Sagala, E. J., Murni, S., \& Abdullah, B. (2008). Performance Appraisal. Jakarta, Indonesia: PT Raja Grafindo Persada.

Tett, R. P., \& Meyer, J. P. (1993). Job satisfaction, organizational commitment, turnover intention, and turnover: path analyses based on meta-analytic findings. Personnel Psychology, 46(2), 259-293.

Vuong, B. N., Tung, D. D., Hoa, N. D., Chau, N. T. N., \& Tusar, H. (2020). An Empirical Assessment of Organizational Commitment and Job Performance: Vietnam Small and MediumSized Enterprises. Journal of Asian Finance, Economics and Business, 7(6), 277-286. https://doi.org/10.13106/jafeb.2020. vol7.no6.277

Werther, W. B., \& Davis, K. (1999). Human Resources \& Personnel Management ( $5^{\text {th }}$ ed.). New York, NY: McGraw-Hill.

Zin, R. M. (1998). Participation and commitment among Malaysian professionals. Selangor, Malaysia: Penerbit Universiti Kebangsaan Malaysia. 